The contents of this letter have been discussed with all interested colleagues in the Institute of Geological Sciences and its publication is approved by the Director.

\title{
References
}

Squirrell, H. C. 1973. The Downtonian-Dittonian Boundary. $J l$ geol. Soc. 129, 205-6. Warren, P. T. 1969. The Siluro-Devonian Boundary. Geol. Mag. 106, 215-16.

Institute of Geological Sciences

J. R. EARP

5 Princes Gate

London SW7 1QN

30th January 1973

\section{The Silurian Devonian boundary}

SIR,-At the request of the editors, I enclose a short statement which summarizes the final recommendation on horizon and locality for boundary stratotype definition of the Silurian-Devonian Boundary that was made to the Commission on Stratigraphy during the meetings of the 24th International Geological Congress, in August, 1972. The full recommendation is published in Geological Newsletter of the IUGS, No. 4, 1972, pages 268-88. The statement reads as follows:

'The Committee on the Silurian-Devonian Boundary recommends that:

1. The Barrandian area of Czechoslovakia be chosen as the type area in which the Silurian-Devonian Boundary is physically defined. This area will constitute, as a whole, an international standard with which all other regions in the world may be compared.

2. Within the Barrandian area, it is further recommended that the section at Klonk near Suchomasty, as described by Chlupáč in Geological Newsletter, 1969 , No. 4 , page 333 , be designated the type section, or boundary stratotype section at which the selected physical horizon shall be defined; and that the section at Budñany near Karlštejn be designated an auxiliary type section that is positively correlatable with Klonk, but yields supplementary paleontological information.

3. That the boundary horizon in the section at Klonk shall be within the 7 to 10 centimetre thick bed No. 20 immediately below the sudden and abundant occurrence of $M$. uniformis and $M$. uniformis angustidens in the upper part of that bed.'

The section at Klonk is described in greater detail in 'The Silurian-Devonian Boundary in the Barrandian' by Ivo Chlupáč, with contributions by Hermann Jaeger and Jana Zikmundova, which was published in the Bulletin of Canadian Petroleum Geology, Volume 20, No. 1, March 1972, pages 104-74.

It is important to realize the boundary is defined at a physical horizon at a single locality. Klonk was chosen after considerable discussion by the members of the Committee. It is quite possible that there are better sections in the world, and these may become known with additional work. The Barrandian sections, however, have a great deal to recommend them, and the reasons for the choice of the Committee are made clear in the final recommendations as published. As far as possible, the Committee attempted to choose the boundary in a succession representing continuous sedimentation, and without any geological event apparent at the boundary horizon. It was chosen in relation to the zone of Monograptus uniformis, but now that the physical horizon has been chosen, the zone graptolite is no longer the defining criterion. The precise horizon within 'bed 20' referred to above will be defined more clearly in a final report supported by photographs of locality and thin sections of the bed itself.

In fact, zone fossils make their appearance in succession across the boundary, and have been found to appear in approximately the same order in five continents. 
Thus conodonts, trilobites, graptolites, brachiopods, and other animal and plant groups must be used in carrying correlations from the defined boundary to other regions of the world where a similar lithology with a similar faunal facies is developed. The Committee has already spent a considerable amount of time in identifying such localities, and some of them are described in their reports published during the last three years in the Geological Newsletter of the IUGS.

The final report to be published by all members of the Committee will summarize once more their appreciation of the boundary in different parts of the world, thus providing 'para-stratotype sections' that may be used in the various regions for accurate correlation into other faunal and floral facies. At the same time it is hoped that a short history of the Committee's work and the reasons for its final decision can be given.

One final comment must be made. The decision emphasizes the astonishing accuracy that can be attained in intercontinental correlation using all available plant and animal groups, rather than one succession of zone fossils of a particular group. It also emphasizes the equally astonishing degree of unanimity that may be reached by scientists speaking many different languages, and, initially, with many different points of view, when problems and disagreements can be aired in an environment involving field geology and individual research directed towards a common end.

\section{J. MCLAREN, Chairman. Silurian-Devonian Boundary Committee,}

Institute of Sedimentary and Petroleum Geology

Geological Survey of Canada

Department of Energy, Mines and Resources

3303-33rd Street N. W.

Calgary, Alberta, Canada

T2L 2 A 7.

28th February, 1973.

\section{5th International Geological Congress, Australia, 1976}

SIR,-The 25th International Geological Congress will be held in Sydney from 16 to 25 August 1976, under the sponsorship of the Australian Academy of Science and the Geological Society of Australia.

Pre- and post-Congress excursions are being arranged throughout Australia, and the Geologists of New Zealand and of Papua New Guinea have also agreed to organize excursions in association with the Congress.

The Organizing Committee is anxious to establish a distribution list for the First Circular, which will be available in October 1973. It will be distributed automatically to those whose names and addresses appear in the List of Registrants for the 24th Congress 1972 , and to major geological institutions. Others who wish to receive it are asked to write as soon as possible to:

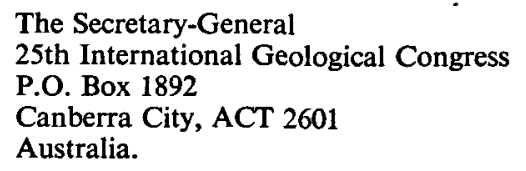

Department of Minerals and Energy Canberra City

N. H. FISHER

Australia

31st January 1973 